\title{
Health promotion of frail elderly individuals and at risk of frailty
}

\author{
Promoção da saúde de idosos frágeis e em risco de fragilização \\ Promoción de la salud de ancianos frágiles y con riesgo de fragilidad
}

\section{Cynthia Roberta Dias Torres Silva' ORCID: 0000-0002-3331-2719}

Khelyane Mesquita de Carvalho' ORCID: 0000-0003-4270-3890

Maria do Livramento Fortes Figueiredo' ORCID: 0000-0003-4938-2807

Fernando Lopes Silva-Júnior' ORCID: 0000-0002-0273-6738

Elaine Maria Leite Rangel Andrade' ORCID: 0000-0002-1772-7439

Lydia Tolstenko Nogueira' ORCID: 0000-0003-4918-6531

'Universidade Federal do Piauí. Teresina, Piauí, Brazil.

How to cite this article:

Silva CRDT, Carvalho KM, Figueiredo MLF, Silva-Júnior FL, Andrade EMLR, Nogueira LT. Health promotion of frail elderly individuals and at risk of frailty.

Rev Bras Enferm. 2019;72(Suppl 2):319-27. doi: http://dx.doi.org/10.1590/0034-7167-2018-0575

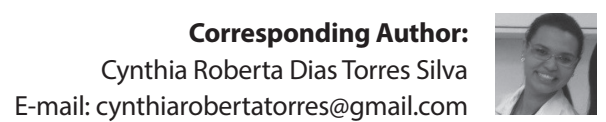

Submission: 07-17-2018

Approval: 09-29-2018

\section{ABSTRACT}

Objective: To identify interventions for the health promotion of frail elderly individuals and those at risk of frailty. Method: Integrative review of the literature performed in the following databases: LILACS, CINAHL, MEDLINE, Web of Science, COCHRANE and Scopus, using the Descriptors: "frail elderly", "aging", "health services for the aged" and "health promotion" combined with Boolean operators "AND" and "OR". Results: Randomized controlled clinical trials (RCTs) classified as level of evidence II represented $82.6 \%$ of studies. Interventions were analyzed according to the following categories: Interventions for the elderly at risk of frailty and Interventions for the frail elderly. Conclusion: The following interventions were identified: educational multiprofessional group meetings, physical training, home visit/home care program, nutrition assessment and supplementation, health maintenance programs and cognitive training; models/ programs of management and monitoring, use of assistive technology devices and hospitalization program for geriatric rehabilitation.

Descriptors: Frail Elderly; Frailty; Aging; Health Services for the Aged; Nursing Care.

\section{RESUMO}

Objetivo: Identificar intervenções para promoção da saúde de idosos frágeis e em risco de fragilização. Método: Revisão integrativa da literatura realizada nas bases de dados: LILACS, CINAHL, MEDLINE, Web of Science, COCHRANE e Scopus, utilizando os Descritores: "frail elderly", "aging", "health services for the aged" e "health promotion", combinados por meio de operadores boleanos "AND" e "OR". Resultados: Ensaios clínicos randomizados controlados (ECRC) classificados como nível de evidência II corresponderam a $82,6 \%$ dos estudos. As intervenções foram analisadas segundo as categorias: Intervenções para idoso em risco de fragilização e Intervenções para o idoso frágil. Conclusão: As intervenções identificadas foram: reuniões educativas de grupos multiprofissionais, treinamento físico, visita domiciliar/programa de cuidados domiciliar, avaliação e suplementação nutricional, programas para manutenção da saúde e treinamento cognitivo; modelos/programas de gestão e monitoramento, uso de dispositivos de tecnologia assistiva e programa de internação para reabilitação geriátrica. Descritores: Idoso Frágil; Fragilidade; Envelhecimento; Saúde do Idoso; Cuidados de Enfermagem.

\section{RESUMEN}

Objetivo: Identificar intervenciones para promover la salud de ancianos frágiles y con riesgo de fragilidad. Método: Revisión integrativa de la literatura realizada en las siguientes bases de datos: LILACS, CINAHL, MEDLINE, Web of Science, COCHRANE y Scopus, utilizando los Descriptores: "frail elderly", "aging", "health services for the aged" y "health promotion", combinados por medio de operadores Booleanos "AND" y "OR". Resultados: Los ensayos clínicos aleatorizados controlados (ECAC) clasificados como nivel de evidencia II correspondieron al $82,6 \%$ de los estudios. Las intervenciones fueron analizadas según las categorías: Intervenciones para ancianos con riesgo de fragilidad e Intervenciones para el anciano frágil. Conclusión: Las intervenciones identificadas fueron: reuniones educativas de grupos multiprofesionales, entrenamiento físico, visita domiciliaria/programa de atención domiciliaria, evaluación y suplementación nutricional, programas para el mantenimiento de la salud y entrenamiento cognitivo; modelos/programas de gestión y monitoreo, uso de dispositivos de tecnología asistiva y programa de internación para rehabilitación geriátrica.

Descriptores: Ancianos Frágiles; Fragilidad; Envejecimiento; Salud del Anciano; Cuidados de Enfermería. 


\section{INTRODUCTION}

Population aging is a phenomenon of great magnitude nationally and internationally. According to estimates, from 2017 to 2050, the number of older people should double in developing countries and will determine specific demands on social and health care services ${ }^{(1)}$. In Brazil, this increase will maximize the number of people in frail situations. The association of this factor with weak social policies of access to health, safety, housing and social security can generate relevant problems ${ }^{(2)}$.

In this perspective, identifying the risk of frailty in the elderly is key, because of the impending functional decline delimiting the transition between active aging and disability. As an emerging physiological syndrome in public health, frailty is a predictive factor of negative health outcomes, such as increased risk of mortality, a decrease in daily life activities (ADL), higher hospitalization, physical limitations, falls and fractures, social withdrawal and delusions ${ }^{(3-4)}$.

Among various terminologies, indicators and models of health assessment, frailty was initially defined by Fried (2001) as a biological syndrome characterized by increased vulnerability caused by the decline in physiological reserve and reduced capacity to respond to endogenous and exogenous stressors ${ }^{(5-6)}$. As this is a clinical state defined by multiple signs and symptoms, in the literature, it is operationally characterized by the clinical phenotype of negative energy balance, sarcopenia, decreased strength and effort tolerance. Frailty is defined by the presence of three out of the five phenotypic criteria, namely: low grip strength, low energy, slow waking speed, low physical activity and/or unintentional weight loss, which must be sustained and self-perpetuated throughout progressive natural events of aging ${ }^{(6-7)}$.

In relation to the prevalence of frailty in community elderly, in a meta-analysis performed with international studies according to the phenotypic criteria, $10.7 \%$ of the elderly were frail, varying from $4.0 \%$ to $59.1 \%{ }^{(8)}$. In Brazil, the prevalence of multidimensional frailty was $47.2 \%$, and it was associated with the following variables: extreme old age people who live without a partner, have a caregiver, have depressive symptoms, osteoarticular disease, and a history of hospitalization and falls in the 12 previous months ${ }^{(3)}$. Frailty is an avoidable condition with potential reversibility when appropriate interventions are adopted to restore the physical, cognitive and nutritional abilities of the elderly person ${ }^{(9)}$.

Some studies present interventions for identifying frailty and strategies for prevention, reduction and delay of adverse health consequences for the elderly and their caregivers ${ }^{(10,11,12,13)}$. However, there are few productions that recognize the role of nurses in identifying and stratifying the risk of frailty of the elderly, as well as their responsibility for adopting evidence-based therapeutic interventions $^{(14)}$.

By understanding the need to address strategies to promote lifestyle changes and analyze evidence to empower the workforce, this study emerges as part of the Nursing thesis titled: "Educational program with telephone follow-up for the elderly at risk of frailty: randomized controlled clinical trial". The thesis was developed by the Study Group on the Multidimensionality of Aging, Health and Nursing (Portuguese acronym: GEMESE), of the Postgraduate Nursing Program at the Universidade Federal do Piauí.

\section{OBJECTIVE}

To identify interventions for the health promotion of frail elderly individuals and those at risk of frailty.

\section{METHOD}

Integrative review of the literature operationalized by the following steps: selection of the study question, establishment of criteria for sample selection and search in the literature, definition of information extracted from selected studies, evaluation of studies included in the review, interpretation of results and presentation of the review ${ }^{(15)}$.

The study question was: Which interventions are used for the health promotion of frail elderly? The PICO strategy was used to design the question by considering that $\mathrm{P}$ (population): frail elderly, I (phenomena of interest): frailty, C (comparison): -, O (outcome): health promotion.

The search of studies was performed in January 2018 in the following databases: Latin American and Caribbean Literature in Health Sciences (LILACS), consulted by the Virtual Health Library (VHL); Cumulative Index to Nursing and Allied Health Literature (CINAHL); Medical Literature Analysis and Retrieval System Online (MEDLINE), via PubMed; Web of Science, via Main Collection (Thomson Reuters Scientific), COCHRANE and Scopus, accessed through the CAPES Portal using the descriptors: "frail elderly", "aging", "health services for the aged" and "health promotion", identified in the Medical Subject Headings (MeSH), Title CINAHL and Descriptors in Health Sciences (DeCS), combined by Boolean operators "AND" and "OR". Uncontrolled descriptors were also used, namely: "frailty", "frailty syndrome", "health vulnerability" and "comprehensive health care".

Legend: Ude- Uncontrolled descriptor

The search strategy used was developed in MEDLINE via PubMed (Figure 1) and adapted to all other databases.

("frail elderly"[MeSH Terms] AND ((("aging"[MeSH Terms] OR "frailty"[All Fields]) OR "frailty syndrome"[All Fields]) OR "health vulnerability"[All Fields])) AND (("health services for the aged"[MeSH Terms] OR "health promotion"[MeSH Terms]) OR "comprehensive health care"[All Fields])

Figure 1 - Search strategy developed for Medline (via PubMed), 2018

In order to include the publications in the review, the following criteria were defined: full articles made available as original articles, methodological designs of clinical trials, including uncontrolled, controlled, randomized and controlled, and almost experimental studies; in English, Spanish and Portuguese with people aged 60 years and over of both sexes, and addressing educational interventions for the health promotion of frail elderly community residents.

We excluded studies in which participants were formal and informal caregivers of the elderly, those with interventions aimed at the elderly in the trans and post-hospital periods, and living in long-term institutions, besides studies with multiprofessional teams without the presence of nurses in the team.

For the collection of information, were followed the recommendations of the checklist Preferred Reporting Items for Systematic Reviews and Meta-Analysis (PRISMA). In the initial search, 957 studies 
were obtained. Of these, 74 studies were selected for full reading and to evaluate if the interventions met the pre-defined inclusion and exclusion criteria, followed by the selection of the final sample of the review (Figure 2).

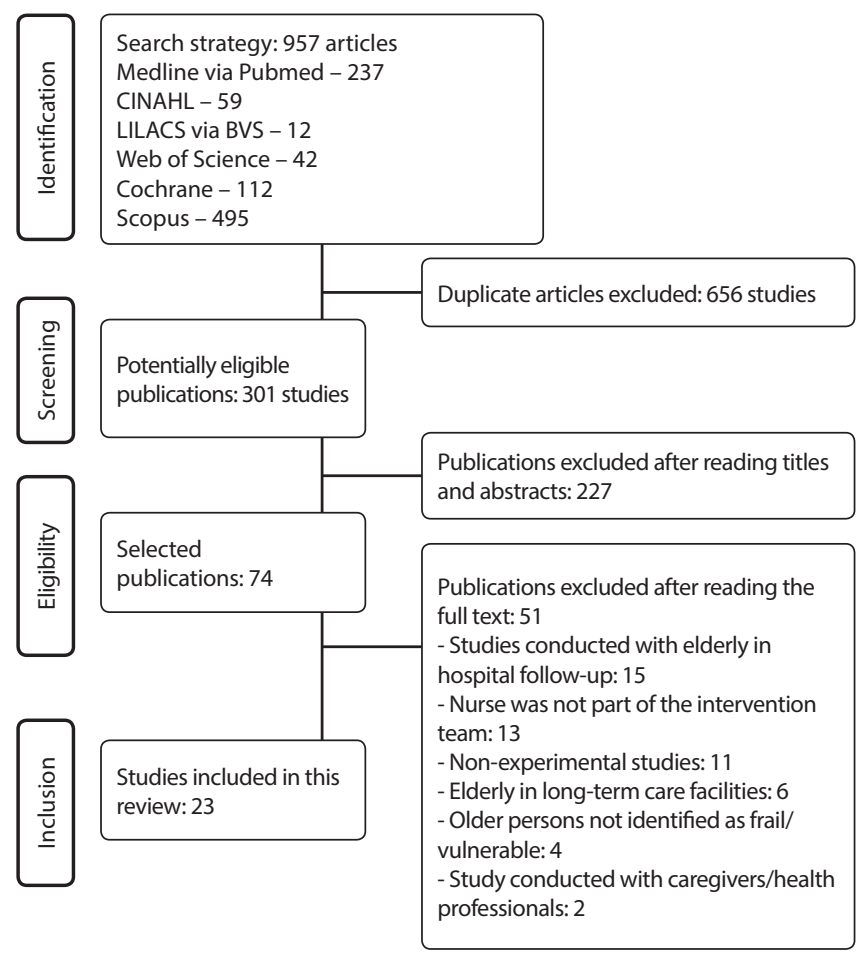

Figure 2 - Search strategy for selection of articles included in the review, 2018

For validation of the selection of publications for analysis and greater consistency, was performed the paired search. The results of the sample selection were analyzed and compared by two independent evaluators. Disagreements were resolved by consensus among reviewers. When necessary, a third reviewer was included to clear the doubts. There were six disagreements (20\%) among reviewers in the final sample selection, which referred to the designs and objectives of studies. After reevaluation, these articles were excluded because they only presented analysis of secondary and evaluative data of health interventions.

For extraction of data from the selected articles, was used an instrument addressing the following items: study design, location, population, description of the intervention and the team involved in its performance, follow-up time, follow-up losses, dependent variable, outcome measures and observed effects.

Then, data were interpreted in an organized way and synthesized by means of a synoptic table with the description of the main aspects. For the interpretation of results and presentation of the review, interventions were discussed based on the functional clinical classification of the elderly, which is subdivided into three groups: robust, at risk of frailty and frail(16).

In addition, in the research were considered the ethical aspects by respecting the authorship of ideas, concepts and definitions present in the articles included in the review.

\section{RESULTS}

The 23 articles selected in this review were developed and published in the following countries: Sweden (21.7\%), USA (17.4\%), Netherlands (13\%) and Canada (13\%); in addition to Japan, Argentina, Singapore, Taiwan, Finland, Spain, New Zealand and Germany with $4.3 \%$ each. According to the year of publication, the distribution was: 1992 (4.3\%), 1996 (4.3\%), 1998 (4.3\%), 1999 (4.3\%), 2000 (4.3\%), 2007 (4.3\%), 2008 (8.7\%), 2010 (17.4\%), 2012 (8.7\%), 2013 (4.3\%), 2014 (8.7\%), 2015 (8.7\%), 2016 (8.7\%) and 2017 (8.7\%).

Regarding the design and level of evidence, $82.6 \%$ of studies were randomized controlled clinical trials (RCTs) classified as level of evidence II, and $17.4 \%$ were quasi-experimental studies classified as level of evidence III.

Chart 1 presents the interventions for health promotion of frail elderly individuals and those at risk of frailty.

Chart 1 - Interventions for the health promotion of frail elderly people and those at risk of frailty according to design, location, population, follow-up time and outcome, 2018

\begin{tabular}{|c|c|c|c|c|}
\hline $\mathbf{N}$ & DESIGN & $\begin{array}{l}\text { LOCATION/ } \\
\text { POPULATION }\end{array}$ & INTERVENTION/ FOLLOW-UP TIME & OUTCOME \\
\hline \multicolumn{5}{|c|}{ Intervention aimed at the elderly at risk of frailty } \\
\hline $\mathrm{A} 1^{(17)}$ & $\begin{array}{c}\text { Quasi- } \\
\text { experimental }\end{array}$ & $\begin{array}{l}\text { USA/59 independent } \\
\text { frail elderly. }\end{array}$ & $\begin{array}{l}\text { Health maintenance program for } \\
\text { regular exercise practice, teaching } \\
\text { on health and physical and mental } \\
\text { wellbeing/ six months. }\end{array}$ & $\begin{array}{l}\text { Clinical improvement in all measurements with } \\
\text { emphasis on systolic blood pressure and range of } \\
\text { motion in the right ankle, and better indices of self- } \\
\text { esteem and life satisfaction. }\end{array}$ \\
\hline $\mathrm{A} 2^{(18)}$ & RCT & $\begin{array}{l}\text { Netherlands } / 330 \\
\text { elderly people with } \\
\text { health problems. }\end{array}$ & $\begin{array}{l}\text { Home visits and multidimensional } \\
\text { geriatric evaluation/18 months. }\end{array}$ & $\begin{array}{l}\text { No effect on the use of health services by the } \\
\text { elderly, and low chance of being cost-effective. }\end{array}$ \\
\hline $\mathrm{A} 3^{(19)}$ & $\begin{array}{l}\text { Quasi- } \\
\text { experimental }\end{array}$ & $\begin{array}{l}\text { Argentina/ } 110 \text { frail } \\
\text { elderly. }\end{array}$ & Home visit/- & $\begin{array}{l}\text { Higher level of knowledge on adequate nutrition, } \\
\text { benefits of physical exercise and preventive } \\
\text { measures for falls. }\end{array}$ \\
\hline$A 4^{(20)}$ & $\begin{array}{c}\text { Quasi- } \\
\text { experimental }\end{array}$ & $\begin{array}{l}\text { Canada/1,501 elderly } \\
\text { individuals at risk of } \\
\text { functional decline. }\end{array}$ & $\begin{array}{l}\text { Program for maintenance of autonomy } \\
\text { (PRISMA)/four years }\end{array}$ & $\begin{array}{l}\text { Fewer cases of functional decline and prevalence } \\
\text { of unmet needs, higher satisfaction and } \\
\text { empowerment. Lower number of visits to } \\
\text { emergency rooms and hospitalizations than } \\
\text { expected in the experimental cohort. }\end{array}$ \\
\hline
\end{tabular}


Chart 1

\begin{tabular}{|c|c|c|c|c|}
\hline $\mathbf{N}$ & DESIGN & $\begin{array}{l}\text { LOCATION/ } \\
\text { POPULATION }\end{array}$ & INTERVENTION/ FOLLOW-UP TIME & OUTCOME \\
\hline $\mathrm{A} 5^{(21)}$ & $\mathrm{RCT}$ & $\begin{array}{l}\text { Sweden } / 459 \\
\text { independent elderly } \\
\text { people in ADL. }\end{array}$ & $\begin{array}{l}\text { Preventive home visits and weekly } \\
\text { multiprofessional group meetings with } \\
\text { one follow-up home visit/three-months. }\end{array}$ & $\begin{array}{l}\text { Delay of deterioration of ADLs compared to a } \\
\text { single preventive home visit. }\end{array}$ \\
\hline$A 6^{(22)}$ & $\mathrm{RCT}$ & $\begin{array}{l}\text { Sweden } / 459 \\
\text { independent elderly } \\
\text { people. }\end{array}$ & $\begin{array}{l}\text { Preventive home visit and weekly } \\
\text { multiprofessional group meetings with } \\
\text { one follow-up home visit/one and two } \\
\text { years. }\end{array}$ & $\begin{array}{l}\text { Reduction of dependency in ADL after one year. } \\
\text { High-level meetings were superior to a preventive } \\
\text { home visit. Significant additional effects were } \\
\text { observed after two years. }\end{array}$ \\
\hline$A 7^{(23)}$ & $\mathrm{RCT}$ & $\begin{array}{l}\text { Sweden } / 459 \\
\text { independent elderly } \\
\text { people in ADL }\end{array}$ & $\begin{array}{l}\text { Preventive home visit and weekly } \\
\text { multiprofessional group meetings with } \\
\text { one follow-up home visit/one and two } \\
\text { years. }\end{array}$ & $\begin{array}{l}\text { Effective in delaying the deterioration of mobility } \\
\text { and maintaining health satisfaction for up to two } \\
\text { years. High-level meetings appear to have a greater } \\
\text { effect than preventive home visits with regard to } \\
\text { delaying the deterioration of self-rated health care } \\
\text { with sustained effect after one year. }\end{array}$ \\
\hline$A 8^{(24)}$ & $\begin{array}{l}\text { Clinical trial } \\
\text { with parallel } \\
\text { groups }\end{array}$ & $\begin{array}{l}\text { Japan/58 elderly } \\
\text { (healthy and pre-frail } \\
\text { women) }\end{array}$ & $\begin{array}{l}\text { Individual physical exercise program/ } \\
\text { one year. }\end{array}$ & $\begin{array}{l}\text { Improvements in advancement and retreat time, } \\
\text { and five-meter walking time tests in the pre-frail } \\
\text { elderly group after the exercise program. }\end{array}$ \\
\hline$A 9^{(25)}$ & $\mathrm{RCT}$ & $\begin{array}{l}\text { Sweden } / 459 \\
\text { independent elderly } \\
\text { people in ADL. }\end{array}$ & $\begin{array}{l}\text { Preventive home visit and weekly } \\
\text { multiprofessional group meetings with } \\
\text { one follow-up home visit/three months, } \\
\text { one and two years. }\end{array}$ & $\begin{array}{l}\text { Favorable effects in delaying the progression of } \\
\text { subjective frailty (experience/feeling of being frail) } \\
\text { measured by fatigue in daily activities for up to } \\
\text { one year. }\end{array}$ \\
\hline $\mathrm{A} 10^{(26)}$ & $\mathrm{RCT}$ & $\begin{array}{l}\text { Canada/ } 236 \\
\text { independent elderly } \\
\text { subjects. }\end{array}$ & $\begin{array}{l}\text { Nurse-based program of home care/ } \\
\text { one year }\end{array}$ & No impact on the outcomes measured. \\
\hline $\mathrm{A} 11^{(27)}$ & $\mathrm{RCT}$ & $\begin{array}{l}\text { Spain/pre-frail } \\
\text { elderly. }\end{array}$ & $\begin{array}{l}\text { Nutritional assessment and physical } \\
\text { activity program (aerobic exercises and } \\
\text { combined strengthening, balance and } \\
\text { coordination exercises)/one year. }\end{array}$ & $\begin{array}{l}\text { Effective in preventing frailty in community pre- } \\
\text { frail elderly subjects. }\end{array}$ \\
\hline \multicolumn{5}{|c|}{ Intervention aimed at the frail elderly } \\
\hline $\mathrm{A} 12^{(28)}$ & $\mathrm{RCT}$ & $\begin{array}{l}\text { USA/167 elderly } \\
\text { newly admitted to } \\
\text { the "personal care at } \\
\text { home" by the Long } \\
\text { Term Care (LTC) } \\
\text { program of the B.C. } \\
\text { Ministry of Health. }\end{array}$ & $\begin{array}{l}\text { Program of home care and home visits } \\
\text { to devise individualized plans/three } \\
\text { years. }\end{array}$ & $\begin{array}{l}\text { Statistically significant differences were found at } \\
24 \text { and } 36 \text { months when analyzing participants' } \\
\text { survival curves. }\end{array}$ \\
\hline $\mathrm{A} 13^{(29)}$ & $\mathrm{RCT}$ & $\begin{array}{l}\text { USA/201 elderly } \\
\text { people with chronic } \\
\text { diseases. }\end{array}$ & $\begin{array}{l}\text { Multicomponent disability prevention } \\
\text { and disease self-management program/ } \\
\text { one year. }\end{array}$ & $\begin{array}{l}\text { Significantly higher levels of physical activity and } \\
\text { participation of the elderly center, and significant } \\
\text { reductions in the use of psychoactive drugs. }\end{array}$ \\
\hline $\mathrm{A} 14^{(30)}$ & $\mathrm{RCT}$ & USA/104 frail elderly. & $\begin{array}{l}\text { Comprehensive functional assessment } \\
\text { and evaluation of the home } \\
\text { environment with home environmental } \\
\text { interventions (Els) and assistive } \\
\text { technology (AT) devices/18 months. }\end{array}$ & $\begin{array}{l}\text { Frail elderly subjects have experienced functional } \\
\text { decline over time. The results indicated a reduction } \\
\text { of the functional decline rate, and reduction of } \\
\text { internal and institutional staff costs through a } \\
\text { systematic approach to provide El and AT. }\end{array}$ \\
\hline $\mathrm{A} 15^{(31)}$ & $\mathrm{RCT}$ & $\begin{array}{l}\text { Canada/142 frail } \\
\text { elderly. }\end{array}$ & Home nursing visits/14 months. & $\begin{array}{l}\text { There was no effect on frailty, only vaccination } \\
\text { coverage was greatly improved. }\end{array}$ \\
\hline $\mathrm{A} 16^{(32)}$ & $\mathrm{RCT}$ & $\begin{array}{l}\text { Finland/741 frail } \\
\text { elderly. }\end{array}$ & $\begin{array}{l}\text { Rehabilitation in rehabilitation centers } \\
\text { and home visits/ three seven-day } \\
\text { hospitalization periods (totaling } 21 \\
\text { days) with assessment at one year. }\end{array}$ & $\begin{array}{l}\text { Viable for use with frail elderly and with } \\
\text { improvement of subjective health. }\end{array}$ \\
\hline $\mathrm{A} 17^{(33)}$ & $\mathrm{RCT}$ & $\begin{array}{l}\text { Netherlands } / 151 \\
\text { elderly people with } \\
\text { cognitive limitations in } \\
\text { performing activities } \\
\text { of daily living and/or } \\
\text { mental wellbeing. }\end{array}$ & $\begin{array}{l}\text { Home visit with multiprofessional } \\
\text { geriatric assessment and management } \\
\text { (drug adjustment, referrals to } \\
\text { specialized services)/six months. }\end{array}$ & $\begin{array}{l}\text { Improvement of functional skills and mental } \\
\text { wellbeing of vulnerable elderly. Higher } \\
\text { effectiveness of primary care for this population. }\end{array}$ \\
\hline $\mathrm{A} 18^{(34)}$ & $\mathrm{RCT}$ & $\begin{array}{l}\text { Germany/651 frail } \\
\text { elderly people }\end{array}$ & $\begin{array}{l}\text { Home visits with assessment and } \\
\text { individualized nursing interventions } \\
\text { and telephone monitoring/18 months. }\end{array}$ & $\begin{array}{l}\text { No beneficial effects in vulnerable and frail elderly } \\
\text { in primary care. }\end{array}$ \\
\hline
\end{tabular}


Chart 1 (concluded)

\begin{tabular}{|c|c|c|c|c|}
\hline $\mathbf{N}$ & DESIGN & $\begin{array}{l}\text { LOCATION/ } \\
\text { POPULATION }\end{array}$ & INTERVENTION/ FOLLOW-UP TIME & OUTCOME \\
\hline$A 19^{(35)}$ & $\mathrm{RCT}$ & $\begin{array}{l}\text { New Zealand } / 351 \\
\text { elderly individuals } \\
\text { at risk of permanent } \\
\text { residential care } \\
\text { placement. }\end{array}$ & $\begin{array}{l}\text { Three, six, } 12,18 \text {, and } 24 \text {-month care } \\
\text { management program. }\end{array}$ & $\begin{array}{l}\text { Reduction of elderly subjects' risk of mortality and } \\
\text { of permanent residential care placement. }\end{array}$ \\
\hline $\mathrm{A} 20^{(36)}$ & $\mathrm{RCT}$ & $\begin{array}{l}\text { Netherlands/346 frail } \\
\text { elderly }\end{array}$ & $\begin{array}{l}\text { Home assessment and individualized } \\
\text { interdisciplinary care with regular } \\
\text { follow-ups/ } 24 \text { months. }\end{array}$ & $\begin{array}{l}\text { No significant differences between groups regarding } \\
\text { disability and health-related quality of life. The elderly } \\
\text { in the intervention group used more primary care } \\
\text { services, but there was no decline in long-term care. }\end{array}$ \\
\hline $\mathrm{A} 21^{(37)}$ & RCT & $\begin{array}{l}\text { Sweden/153 frail } \\
\text { elderly. }\end{array}$ & $\begin{array}{l}\text { Home visits/three, six, nine and } 12 \\
\text { months. }\end{array}$ & $\begin{array}{l}\text { No differences between groups. However, the } \\
\text { intervention group performed leisure activities and } \\
\text { physical activities to a greater extent in the three- } \\
\text { month period. }\end{array}$ \\
\hline \multicolumn{5}{|c|}{ Intervention aimed at the elderly at risk of frailty and frail } \\
\hline$A 22^{(38)}$ & $\mathrm{RCT}$ & $\begin{array}{l}\text { Taiwan/310 pre-frail } \\
\text { and frail community- } \\
\text { dwelling elderly. }\end{array}$ & $\begin{array}{l}\text { Comprehensive geriatric assessment (CGA) } \\
\text { followed by appropriate intervention } \\
\text { by medication adjustment, exercise } \\
\text { instruction, nutritional support, physical } \\
\text { rehabilitation, social worker consultation } \\
\text { and referral to specialists/six months. }\end{array}$ & $\begin{array}{l}\text { Favorable outcome in frail and pre-frail elderly } \\
\text { because of the frailty status. Patients' frailty status } \\
\text { tended to improve at the six-month follow-up, } \\
\text { although without statistical significance. }\end{array}$ \\
\hline $\mathrm{A} 23^{(39)}$ & $\mathrm{RCT}$ & $\begin{array}{l}\text { Singapore/ } 246 \text { pre- } \\
\text { frail and frail elderly. }\end{array}$ & $\begin{array}{l}\text { Nutritional supplementation, cognitive } \\
\text { training, physical training, combination } \\
\text { treatment and usual care control/zero } \\
\text { months, three months, six months and } \\
12 \text { months. }\end{array}$ & $\begin{array}{l}\text { The status and scores of frailty for } 12 \text { months were } \\
\text { reduced in all groups, including the control, and } \\
\text { were significantly higher in groups of nutritional } \\
\text { intervention, cognitive intervention, physical } \\
\text { intervention and combination treatment. The } \\
\text { beneficial effects were observed at three months and } \\
\text { six months, and persisted within } 12 \text { months of the } \\
\text { measurement. }\end{array}$ \\
\hline
\end{tabular}

\section{DISCUSSION}

\section{Interventions for the elderly at risk of frailty}

The interventions for elderly individuals at risk of frailty are strategies directed at independent people in all basic or instrumental activities of daily living (ADL), who have one or more predictive conditions of imminent functional decline and mortality, such as sarcopenia, mild cognitive impairment, multiple comorbidity defined by polypathy or polypharmacy or recent hospitalization ${ }^{(16)}$.

In this review, the interventions for elderly individuals at risk of frailty combined multiple proposals in an associated or isolated way, such as educational multiprofessional group meetings, physical training, home visits/home care programs, nutrition assessment and supplementation, health maintenance programs aimed at stimulating wellbeing and autonomy, and cognitive training.

Group educational activities with follow-up visits at home were effective interventions for the health promotion of elderly individuals at risk of frailty and had positive effects on self-evaluation of health ${ }^{(23)}$, delayed progression of subjective frailty measured by fatigue in daily activities ${ }^{(25)}$, and deterioration ${ }^{(21)}$ and extent of ADL dependence after one year ${ }^{(22)}$.

The effectiveness of complex health promotion strategies in aging is associated with the discussion of multidimensional aging and the need for strategies for self-care and coping with difficulties. Strengthening the belief in self-efficacy among participants favors empowerment and self-esteem and directly stimulates decision-making and behavior change $\mathrm{e}^{(21-23,25)}$.
Thus, in addition to a problem-solving strategy, in group discussions with a multiprofessional approach, a wide range of information and knowledge can be addressed, and is favored the critical reflection with transformation of knowledge for problem solving from a new perspective. A positive view of aging is established, which fosters self-care, co-responsibility for the health of those involved and the encouragement of a healthy lifestyle. In addition to an educational reinforcement tool, discussions are effective strategies for the health promotion of lonely elderly people who need social support ${ }^{(40)}$.

Home visits and home care programs are the most historically used tools in the field of community health ${ }^{(41)}$, have positive results in restoring health and functional status, and minimize mortality rates and number of hospitalizations ${ }^{(42)}$.

Interventions of home visits for the health promotion of vulnerable elderly people favor the bonding, strengthen the information in health education ${ }^{(43)}$, and improve the level of knowledge about proper nutrition, the benefits of exercise and preventative measures for falls ${ }^{(19)}$. However, this intervention has controversial efficacy and ineffective results for non-frail elderly people with easy access to medical care, since by living independently in an environment of low programmatic vulnerability, they do not need intensive and proactive health interventions ${ }^{(18,26)}$.

In addition to educational modalities, physical training and nutritional supplementation are effective interventions for improving aerobic capacity tests in pre-frail elderly ${ }^{(24)}$, for preventing frailty in the elderly ${ }^{(27)}$, and for reducing frailty scores with persistent effect in up to 12 months $^{(39)}$. 
Clinical strategies for improving and encouraging physical exercise practice are one of the main rehabilitation components of elderly individuals at risk of frailty ${ }^{(10,44)}$ because they act on sarcopenia. This is a key feature of frailty in the elderly and one of the main determinants of adverse health outcomes, that also results in loss of strength and muscle quality, and impairs balance, ability to move, and endurance ${ }^{(45)}$.

Resistance training and adequate intake of protein and energy favor the management of weight loss and resistance training, and delay the decline of muscle mass and strength. Physical activity programs are an easily accepted intervention by the elderly at social risk of depression, lonely or with established physical disability. These programs also have a physiological effect and collaborate with socialization ${ }^{(27)}$.

Cognitive training stands out as a non-pharmacological intervention modality for the elderly, acts on the plasticity of intellectual functioning and is a promising alternative to alleviate or delay the effects of aging ${ }^{(46)}$. Reestablishing the capacity of understanding and solving everyday problems and the cognitive training have an impact on memory, attention, reasoning and speed of processing, among other functions that favor the maintenance of autonomy along with humor/behavior, and directly affect the frailty ${ }^{(39)}$.

Finally, educational programs for maintaining physical and mental wellbeing that encourage regular exercise practice, participation in groups ${ }^{(17)}$ and programs to strengthen the autonomy of the elderly at risk of frailty ${ }^{(20)}$ with effective modalities for the clinical improvement and reduction of the number of cases of functional decline, favor the self-esteem and life satisfaction and attenuate the prevalence of unmet needs.

These evidences portray the international tendency to combine strategies for transmitting information with screening/ counseling actions, which reinforce the individuals' capacity of decision and command, increase satisfaction and empowerment, and favor the management, monitoring and control of the course of illness and behavioral changes for a sustained period of time $\mathrm{e}^{(16,47,48)}$.

\section{Interventions for the frail elderly}

Interventions for frail elderly are measures for the elderly with functional dependence in $A D L$, and may or may not be associated with difficult-to-manage health conditions, hence suggest a high potential for functional gain or quality of life through specialized geriatric-gerontological follow-up ${ }^{(16)}$.

Interventions targeted to frail elderly subjects were: models/ programs of management and monitoring with evaluation visits and multiprofessional geriatric management ${ }^{(28,31,33-36,38)}$; multicomponent program of disability prevention and disease self-management ${ }^{(29)}$; comprehensive functional assessment and evaluation of their home environment with home environmental interventions (Els) and Assistive Technology Devices (AT) ${ }^{(30)}$; and hospitalization program for geriatric rehabilitation ${ }^{(32)}$.

From the establishment of functional decline, strategies for health promotion are directed to the home environment, which is a favorable space for humanized care and centralized in the potentialities and needs of the person served ${ }^{(49)}$.
Community care management strategies aligned with family medical care services can reduce the risk of mortality among the elderly and the length of stay in residential care ${ }^{(35)}$, improve the functional skills and mental wellbeing of vulnerable elderly ${ }^{(33)}$ and consequently, improve their frailty status ${ }^{(38)}$ and survival rates ${ }^{(28)}$.

The need for multiprofessional home care is noteworthy, since it favors the adjustment of medication, instruction of physical exercises, nutritional support, substance use, physical rehabilitation and referral to specific care sectors ${ }^{(38)}$. Developing an individualized health plan according to individuals' wishes and needs favors the establishment of goals, development of personal health skills and appropriate referral to adequate community services. It also provides essential stress control and emotional support for participation and social inclusion ${ }^{(28)}$.

Organized medical assistance with complementary communitybased interventions delimits the organization of new models of management and health care that provide clinical follow-up and rehabilitation, increased levels of physical activity, group participation, and a significant reduction in the use of psychoactive drugs, which represents a promising direction for research and practice ${ }^{(29)}$.

The use of products, methodologies and practices of assistive technology with frail elderly people facilitates the performance of daily activities and promotes functional independence ${ }^{(30)}$. Dealing with the multiple modifications inherent in aging enhances the teaching-learning process, and facilitates the knowledge exchange and improvement of skills $s^{(50)}$.

Regarding individual home-based intervention practices, the results of studies included in this review were not conclusive regarding the effectiveness of interdisciplinary home-based intervention with regular personal or telephone follow-up as a strategy for the care of frail elderly $y^{(31,34,36)}$.

Despite the greater use of primary care services and vaccination coverage among participants ${ }^{(31)}$, disability did not decline and health-related quality of life in long-term care did not increase ${ }^{(36)}$. These results demonstrate the need for greater integration with primary care practices in the management of complex health needs, such as the adequate selection of participants and sensitive measures for the assessment of specific health effects ${ }^{(34)}$.

There are also beneficial effects of hospitalization in rehabilitation centers with home monitoring that improve subjective health ${ }^{(32)}$, and home visits that act in the practice of social and leisure activities. These factors indicate an important gap in care to people with restricted functionality and social participation that can be solved with psychological and cultural actions, which reaffirms bonds and favorable therapeutic relationships ${ }^{(37)}$.

\section{Limitations of the study}

One of the limitations of this review was the inclusion of studies only with participation of nurses, which restricted the results to specific practices and models of this area of performance. There was also a gap in the production of interventions and complex technologies in Nursing, which can be explained by the timid participation of these professionals in the operationalization of technological resources in health for rehabilitation. 


\section{Contributions to the area of nursing, health or public policy}

The conditions of frailty and especially pre-frailty, should be the focus in the planning and operationalization of the elderly's health, since these are predictive conditions of incapacities and dysfunction. Health education actions aimed at elderly individuals at risk of frailty or with established functional decline must include the complexity of aging through assistive and particularized resources and technologies that value and recognize the necessary desires, values and beliefs to maintain self-care, self-esteem and self-efficacy.

\section{CONCLUSION}

Among the interventions for the health promotion of elderly individuals at risk of frailty or frail, the selected articles aimed at educational multiprofessional group meetings, physical training, home visits/home care programs, nutritional assessment and supplementation, programs for health maintenance and cognitive training; in addition to models/programs of management and monitoring, the use of assistive technology devices and hospitalization programs for geriatric rehabilitation.

In view of the above, frailty is a challenge for gerontological care teams. In the last two decades, complex interventions have been prioritized in the care of frail elderly or those at risk of frailty. In addition to targeting the implicit inequalities in aging, such interventions enable the empowerment and development of the necessary skills and attitudes for adapting to changes of aging.

As this is a multidimensional problem, multiple or combined interventions with the support of the community and primary care services are necessary for properly managing the changes associated with the decline of homeostatic reserves inherent to senescence and for guiding the rehabilitation of disabilities.

The development of studies aimed at creating and developing validated translational tools for the tracking, follow-up and monitoring of vulnerable individuals is recommended for strengthening health systems for comprehensive care for the elderly.

\section{REFERENCES}

1. World Health Organization (WHO). World Population Ageing. Department of Economic and Social Affairs, Population Division; 2017 [cited 2018 May 22]. Available from: http://www.un.org/en/development/desa/population/theme/ageing/WPA2017.shtml

2. Alvarez AM, Sandri JVA. Population aging and the Nursing commitment. Rev Bras Enferm. 2018;71(2): 722-3. doi: 10.1590/0034-7167-201871sup201

3. Carneiro JA, Cardoso RR, Durães MS, Guedes MCA, Santos FL, Costa FM, et al. Frailty in the elderly: prevalence and associated factors. Rev Bras Enferm. 2017;70(4):747-52. doi: 10.1590/0034-7167-2016-0633

4. Fhon JSV, Rodrigues RAP, Neira WF, Huayta VMR, Robazzi MLC. Fall and its association with the frailty syndrome in the elderly: systematic review with meta-analysis. Rev Esc Enferm USP. 2016;50(6):1005-13. doi: 10.1590/s0080-623420160000700018

5. Moraes EM, Carmo JA, Moraes FL, Azevedo RS, Machado CJ, Montila DER. Clinical-Functional Vulnerability Index-20 (IVCF-20): rapid recognition of frail older adults. Rev Saúde Pública [Internet]. 2016 [cited 2018 May 22];50(81). Available from: http://www.scielo.br/pdf/rsp/ v50/0034-8910-rsp-S1518-87872016050006963.pdf

6. Fried LP, Tangen CM, Walston J, Newman AB, Hirsch C, Gottdiener J, et al .Frailty in older adults: evidence for a phenotype. J Gerontol Series A [Internet]. 2001 [cited 2018 May 22];56(3):146-56. Available from: https://academic.oup.com/biomedgerontology/article/56/3/M146/545770

7. Xue QL. The Frailty Syndrome: Definition and Natural History. Clin Geriatr Med [Internet]. 2011 [cited 2018 May 24];27(1):1-15. Available from: https://www.ncbi.nlm.nih.gov/pubmed/21093718

8. Collard RM, Boter H, Schoevers RA, Oude Voshaar RC. Prevalence of Frailty in Community-Dwelling Older Persons: A Systematic Review. J Am Geriatr Soc [Internet]. 2012 [cited 2018 May 24];60(8):1487-92. Available from: https://onlinelibrary.wiley.com/doi/ abs/10.1111/j.1532-5415.2012.04054.x

9. Caballero-Mora MA, Rodriguez-Mañas L. STOPPFrail: a misleading name for a potentially useful tool. Age Ageing [Internet]. 2017 [cited 2018 May 24];46(5):874-5. Available from: https://academic.oup.com/ageing/article-abstract/46/5/874/4079772

10. Lee Ping-Hsueh, LeeYow-Shan, Chan Ding-Cheng. Interventions targeting geriatric frailty: a systemic review. J Clin Gerontol Geriatr [Internet]. 2012 [cited 2018 May 24];3(2):47-52. Available from: https://www.sciencedirect.com/science/article/pii/S2210833512000238

11. Puts MTE, Toubasi S, Andrew MK, Asche MC, Ploeg J, Atkinson E, et al. Interventions to prevent or reduce the level of frailty in communitydwelling older adults: a scoping review of the literature and international policies. Age Ageing [Internet]. 2017 [cited 2018 May 24];46(3):383-92. Available from: https://www.ncbi.nlm.nih.gov/pmc/articles/PMC5405756/

12. Lee L, Patel T, Hillier LM, Maulkhan N, Slonim K, Costa A. Identifying frailty in primary care: a systematic review. Geriatr Gerontol Int [Internet]. 2017 [cited 2018 May 24];17(10):1358-77. Available from: https://onlinelibrary.wiley.com/doi/full/10.1111/ggi.12955

13. Lee L, Patel T, Costa A, Bryce E, Hillier LM, Slonim K, et al . Screening for frailty in primary care. Can Fam Physician [Internet]. 2017[cited 2018 May 24];63(1):e51-e57. Available from: https://www.ncbi.nlm.nih.gov/pmc/articles/PMC5257239/

14. Uchmanoxicz I, Jankowska- Polanska B, Wleklik M, Lisiak M, Gobbens R. Frailty Syndrome: nursing Interventions. SAGE Open Nurs[Internet]. 2018 [cited 2018 May 24];4: p. 1-11. Available from: journals.sagepub.com/doi/pdf/10.1177/2377960818759449

15. Whittemore R, Knafl K. The integrative review: updated methodology. J Adv Nurs [Internet]. 2005;52(5):546-53. 
16. Moraes EM, Moraes FL. Avaliação multidimensional do idoso. 5 ed. Belo Horizonte: Folium; 2016. 248 p.

17. Dungan JM, Brown AV, Ramsey MA. Health maintenance for the independent frail older adult: can it improve physical and mental wellbeing? J Adv Nurs [Internet]. 1996 [cited 2018 May 24];23(6):1185-93. Available from: https://www.ncbi.nlm.nih.gov/pubmed/8796467

18. Bouman A, van Rossum E, Evers S, Ambergen T, Kempen G, Knipschild P. Effects on health care use and associated cost of a home visiting program for older people with poor health status: a randomized clinical trial in the Netherlands. J Gerontol A Biol Sci Med Sci [Internet]. 2008 [cited 2018 May 24];63(3):291-7. Available from: https://www.ncbi.nlm.nih.gov/pubmed/18375878

19. Barrios MDM, Pardo LHS, Ceballo GC. Fragilidad em el adulto mayor: intervención educativa sobre los cuidados em el anciano. MEDICIEGO [Internet]. 2010 [cited 2018 May 24];16(Supl.2). Available from: http://www.bvs.sld.cu/revistas/mciego/vol16_supl2_10/pdf/t5.pdf

20. Hébert R, Raîche M, Dubois MF, Gueye NR, Dubuc N, Tousignant M. Impact of PRISMA, a coordination-type integrated service delivery system for frail older people in Quebec (Canada):a quasi-experimental study. J Gerontol B Psychol Sci Soc Sci [Internet]. 2010 [cited 2018 May 24];65B(1):107-18. Available from: https://www.ncbi.nlm.nih.gov/pubmed/19414866

21. Gustafsson S, Wilhelmson K, Eklund K, Gosman-Hedström G, Zidén L, Kronlöf GH, et al. Health-promoting interventions for persons aged 80 and older are successful in the short term- results from the randomized and three-armed elderly persons in the risk zone study. J Am Geriatr Soc [Internet]. 2012 [cited 2018 May 24];60(3):447-54. Available from: https://www.ncbi.nlm.nih.gov/pubmed/22409735

22. Gustafsson S, Eklund K, Wilhelmson K, Edberg AK, Johansson B, Kronlöf GH, et al. Long-term outcome for ADL following the healthpromoting RCT--elderly persons in the risk zone. Gerontologist [Internet]. 2013 [cited 2018 May 24];53(4):654-63. Available from: https:// www.ncbi.nlm.nih.gov/pubmed/22936539

23. Behm L, Wilhelmson K, Falk K, Eklund K, Zidén L, Dahlin-Ivanoff S. Positive health outcomes following health-promoting and diseasepreventive interventions for independent very old persons: long-term results of the three-armed RCT elderly persons in the risk zone. Arch Gerontol Geriatr [Internet]. 2014 [cited 2018 May 24];58(3):376-83. Available from: https://www.ncbi.nlm.nih.gov/pubmed/24462053

24. Sugimoto H, Demura S, Nagasawa Y, Shimomura M. Changes in the physical functions of pre-frail elderly women after participation in a 1-year preventative exercise program. Geriatr Gerontol Int [Internet]. 2014 [cited 2018 May 24];14 (4):975-82. Available from: https://www. ncbi.nlm.nih.gov/pubmed/24299293

25. Behm L, Eklund K, Wilhelmson K, Zidén L, Gustafsson S, Falk K, et al. Health promotion can postpone frailty: results from the RCT elderly persons in the risk zone. Public Health Nurs [Internet]. 2016 [cited 2018 May 24];33(4):303-15. Available from: https://www.ncbi.nlm.nih.gov/pubmed/26568469

26. Godwin M, Gadag V, Pike A, Pitcher H, Parsons K, McCrate F, et al. A randomized controlled trial of the effect of an intensive 1-year care management program on measures of health status in independent, community-living old elderly: the Eldercare project. Fam Pract [Internet]. 2016 [cited 2018 May 24];33(1):37-41. Available from: https://www.ncbi.nlm.nih.gov/pubmed/26560094

27. Serra-Prat M, Sist X, Domenich R, Jurado L, Saiz A, Roces A, et al. Effectiveness of an intervention to prevent frailty in pre-frail communitydwelling older people consulting in primary care: a randomised controlled trial. Age Ageing [Internet]. 2017 [cited 2018 May 24];46 (3):401407. Available from: https://www.ncbi.nlm.nih.gov/pubmed/28064172

28. Hall N, Beck P, Johnson D, Mackinnon K, et al. Randomized trial of a health promotion program for frail elders. Canadian J Ageing [Internet]. 1992 [cited 2018 May 24];11(1):72-91. Available from: https://doi.org/10.1017/S0714980800014537

29. Leveille SG, Wagner EH, Davis C, Grothaus L, Wallace J, LoGerfo M, et al. Preventing disability and managing chronic illness in frail older adults: a randomized trial of a community-based partnership with primary care. J Am Geriatr Soc [Internet]. 1998 [cited 2018 May 24];46(10):1191-8. Available from: https://www.ncbi.nlm.nih.gov/pubmed/9777899

30. Mann WC, Ottenbacher KJ, Fraas L, Tomita M, Granger CV. Effectiveness of assistive technology and environmental interventions in maintaining independence and reducing home care costs for the frail elderly: a randomized controlled trial. Arch Fam Med [Internet]. 1999 [cited 2018 May 24];8(3):210-7. Available from: https://www.ncbi.nlm.nih.gov/pubmed/10333815

31. Dalby DM, Sellors JW, Fraser FD, Fraser C, Van Ineveld C, Howard M. Effect of preventive home visits by a nurse on the outcomes of frail elderly people in the community: a randomized controlled trial. CMAJ [Internet]. 2000 [cited 2018 May 24];162(4):497-500. Available from: https://www.ncbi.nlm.nih.gov/pubmed/10701382

32. Hinkka K, Karppi SL, Pohjolainen T, Rantanen T, Puukka P, Tilvis R. Network-based geriatric rehabilitation for frail elderly people: feasibility and effects on subjective health and pain at one year. J Rehabil Med [Internet]. 2007 [cited 2018 May 24];39 (6):473-8. Available from: https://www.ncbi.nlm.nih.gov/pubmed/17624482

33. Melis RJ, Van Eijken MI, Teerenstra S, Van Achterberg T, Parker SG, Borm GF, et al. A randomized study of a multidisciplinary program to intervene on geriatric syndromes in vulnerable older people who live at home. J Gerontol A Biol Sci Med Sci [Internet]. 2008 [cited 2018 May 24];63(3):283-90. Available from: https://www.ncbi.nlm.nih.gov/pubmed/18375877

34. Van Hout HP, Jansen AP, Van Marwijk HW, Pronk M, Frijters DF, Nijpels G. Prevention of adverse health trajectories in a vulnerable elderly population through nurse home visits: a randomized controlled trial. J Gerontol A Biol Sci Med Sci [Internet]. 2010 [cited 2018 May 24];65(7):734-42. Available from: https://www.ncbi.nlm.nih.gov/pubmed/20457579

35. Parsons M, Senior H, Kerse N, Chen MH, Jacobs S, Vanderhoorn S, et al. Should care managers for older adults be located in primary care? a randomized controlled trial. J Am Geriatr Soc [Internet]. 2012 [cited 2018 May 24];60(1):86-92. Available from: https://www.ncbi.nlm.nih. gov/pubmed/22239292

36. Metzelthin SF, van Rossum E, Hendriks MR, De Witte LP, Hobma SO, Sipers W, et al. Reducing disability in community-dwelling frail older people: cost-effectiveness study alongside a cluster randomised controlled trial. Age Ageing [Internet]. 2015 [cited 2018 May 
Health promotion of frail elderly individuals and at risk of frailty Silva CRDT, Carvalho KM, Figueiredo MLF, Silva-Júnior FL, Andrade EMLR, Nogueira LT.

24];44(3):390-6. Available from: https://www.ncbi.nlm.nih.gov/pubmed/25566783

37. Granbom M, Kristensson J, Sandberg M. Effects on leisure activities and social participation of a case management intervention for frail older people living at home: a randomized controlled trial. Health Soc Care Community [Internet]. 2017 [cited 2018 May 24];25 (4):1416-29. Available from: https://www.ncbi.nlm.nih.gov/pubmed/28295847

38. $\mathrm{Li} \mathrm{CM}$, Chen CY, Li CY, Wang WD, Wu SC. The effectiveness of a comprehensive geriatric assessment intervention program for frailty in community-dwelling older people: a randomized, controlled trial. Arch Gerontol Geriatr [Internet]. 2010 [cited 2018 May 24];50 (1):39-42. Available from: https://www.ncbi.nlm.nih.gov/pubmed/20171455

39. Ng TP, Feng L, Nyunt MS, Feng L, Niti M, Tan BY. Nutritional, physical, cognitive, and combination interventions and frailty reversal among older adults: a randomized controlled trial. Am J Med [Internet]. 2015 [cited 2018 May 24];128(11):1225-36. Available from: https://www. ncbi.nlm.nih.gov/pubmed/26159634

40. Gustafsson S, Berglund H, Faronbi J, Barenfeld E, Ottenvall Hammar I. Minor positive effects of health-promoting senior meetings for older community-dwelling persons on loneliness, social network, and social support. Clin Interv Aging [Internet]. 2017 [cited 2018 May 24];12(7):1867-77. Available from: https://www.ncbi.nlm.nih.gov/pubmed/29158669

41. Santos GS, Cunha IC. Visita domiciliar a idosos: características e fatores associados. Rev Enferm C O Mineiro [Internet]. 2017 [cited 2018 May 24];7:e1271. Available from: http://www.seer.ufsj.edu.br/index.php/recom/article/view/1271

42. Markle-Reid M, Weir R, Browne G, Roberts J, Gafni A, Henderson S. Health promotion for frail older home care clients. J Adv Nurs [Internet]. 2006 [cited 2018 May 24];54(3):381-95. Available from: https://www.ncbi.nlm.nih.gov/pubmed/16629922

43. Dias JJ, Mendes Santos FLLS, Oliveira FKF. Visita domiciliar como ferramenta de promoção da saúde do pé diabético amputado. Rev Enferm UFPE [Internet]. 2017 [cited 2018 May 24];11(12):5464-70. Available from: https://periodicos.ufpe.br/revistas/revistaenfermagem/article/ viewFile/22976/25520

44. Hassani A, Kubicki A, Brost V, Mourey F, Yang F. Kinematic analysis of motor strategies in frail aged adults during the Timed Up and Go: how to spot the motor frailty? Clin Interv Aging [Internet]. 2015 [cited 2018 May 24];26(10):505-13. Available from: https://www.ncbi.nlm.nih. gov/pmc/articles/PMC4345997/

45. Silva RB, Aldoradin-Cabeza H, Eslick GD, Phu S, Duque G. The effect of physical exercise on frail older persons: a systematic review. J Frailty Aging [Internet]. 2017 [cited 2018 May 24];6(2):91-6. Available from: https://www.ncbi.nlm.nih.gov/pubmed/28555710

46. Golino MT, Flores-Mendoza CE. Desenvolvimento de um programa de treino cognitivo para idosos. Rev Bras Geriatr Gerontol [Internet]. 2016 [cited 2018 May 24];19(5):1981- 2256. Available from: http://www.scielo.br/pdf/rbgg/v19n5/1809-9823-rbgg-19-05-00769.pdf

47. Chang Ks, Tsai WH, Tsai CH, Yeh HI, Chiu PH, Chang YW. Effects of health education programs for the elders in community care centers: evaluated by health promotion. Int J Gerontol[Internet]. 2017 [cited 2018 May 24];11(2):109-13. Available from: https://www.sciencedirect. com/science/article/pii/S1873959817301321

48. Koo KM, Park CH, Kim CJ. Development of strategies for changing in physical activity behaviors on older adults with disabilities. J Exerc Rehabil [Internet]. 2017 [cited 2018 May 24];13(6):676-83. Available from: https://www.ncbi.nlm.nih.gov/pmc/articles/PMC5747203/

49. Andrade AM, Silva KL, Seixas CT, Braga PP. Nursing practice in home care: an integrative literature review. Rev Bras Enferm [Internet]. 2017 [cited 2018 May 24];70 (1):210-219. Available from: http://dx.doi.org/10.1590/0034-7167-2016-0214

50. Gradim LC, Castro SS, Tavares DM, Cavalcanti A. Mapeamento de recursos de tecnologia assistiva utilizados por idosos. Rev Ter Ocup Univ [Internet]. 2016 [cited 2018 May 24];27 (1):72-9. Available from: http://www.revistas.usp.br/rto/article/view/104106 